02 Royal Netherlands Institute for Sea Research

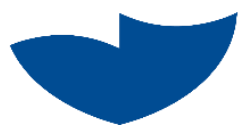

This is a postprint of:

Hout, C.M. van der, Gerkema, T., Nauw, J.J. \& Ridderinkhof, H. (2015). Observations of a narrow zone of high suspended particulate matter (SPM) concentrations along the Dutch coast. Continental Shelf Research, 95, 27-38

Published version: $\underline{\mathrm{dx} . \text { doi.org/10.1016/j.csr.2015.01.002 }}$

Link NIOZ Repository: www.vliz.be/nl/imis?module=ref\&refid=245936

[Article begins on next page]

The NIOZ Repository gives free access to the digital collection of the work of the Royal Netherlands Institute for Sea Research. This archive is managed according to the principles of the Open Access Movement, and the Open Archive Initiative. Each publication should be cited to its original source - please use the reference as presented.

When using parts of, or whole publications in your own work, permission from the author(s) or copyright holder(s) is always needed. 


\title{
Observations of a narrow zone of high suspended particulate matter (SPM) concentrations along the Dutch coast
}

\author{
Carola M. van der Hout*, Theo Gerkema*, Janine N. Nauw*, Herman Ridderinkhof* \\ * Royal Netherlands Institute for Sea Research (NIOZ), Postbus 59, 1790 AB Den Burg, The \\ Netherlands. \\ Contact: carola.van.der.hout@nioz.nl, theo.gerkema@nioz.nl, janine.nauw@nioz.nl, \\ herman.ridderinkhof@nioz.nl.
}

\section{Abstract}

The objective of the study described in this paper is to localize the transport path of suspended particulate matter (SPM) in the Dutch coastal zone in the southern North Sea. It is known that a large mass of SPM is transported northward from the Strait of Dover, which is however mostly hidden from satellite and other surface measurements. The study area is located at $80 \mathrm{~km}$ north of the Rhine-Meuse estuary mouth in the far-field plume of the region of freshwater influence (ROFI). We investigate the occurrence and persistence of a turbidity maximum zone (TMZ) in an area closer to the coast than studied in previous observational programs. Shipboard measurements of vertical profiles of SPM concentrations, density and current velocities with a high cross-shore spatial resolution are presented. A turbidity maximum zone is found at a distance between 0.5 and $3 \mathrm{~km}$ from the coast along $30 \mathrm{~km}$ of the coastline. Observed concentrations are shown to vary strongly within a tidal cycle, and also between contrasting meteorological conditions in terms of the springneap tidal cycle, the significant wave height and the wind force. Temporary stratification is observed during spring tides, and occurs on the ebb phase of the tidal cycle. Cross-shore transports at a transect perpendicular to the coast show an accumulation of SPM in the TMZ within one tidal cycle. Possible mechanisms for this accumulation close to the coast are discussed. 


\section{Keywords}

turbidity maximum zone, in-situ measurements, periodic stratification, ROFI, cross-shore SPM transport, resuspension

\section{Highlights}

- SPM concentrations were measured in the far-field plume of the Rhine ROFI .

- A turbidity maximum zone (TMZ) is observed within $5 \mathrm{~km}$ from the coast.

- In the TMZ, cross-shore accumulation occurs during calm weather. 


\section{Introduction}

Along the Dutch coast a large mass of suspended particulate matter (SPM) is transported northward, but it is often hidden from satellite and other surface measurements (Visser et al., 1991; Joordens et al., 2001; Geyer et al., 2004; Fettweis et al., 2007; Pietrzak et al., 2011). SPM in the Dutch coastal zone originates predominantly from the Strait of Dover. A well-accepted estimate of the yearly average SPM transport though the Strait of Dover is $44 \mathrm{Mton} / \mathrm{yr}$, with seasonal variability between 22 and 58 Mton/yr (McManus and Prandle, 1997; Fettweis and Van den Eynde, 2003). Other studies show a wide range of the yearly averaged SPM transport between 13 and 44 Mton/yr (Fettweis and Van den Eynde, 2003; De Kok, 2004). The variability in these estimates reflects both the limited nature of the available field data and the high yearly variability of the transport itself (Van Alphen, 1990; McManus and Prandle, 1997; Fettweis and Van den Eynde, 2003). The SPM transport though the Strait of Dover splits about 50-50 over the coasts of the UK and Belgium (McManus and Prandle, 1997; Fettweis et al., 2007). Following the SPM northward, it remains close to the coast and only temporary settling occurs in the Belgian turbidity maximum zone at the Flemish banks and in the Rhine-Meuse estuary (Fettweis and Van den Eynde, 2003, De Nijs, 2012). Possibly erosion of the Flemish banks contributes up to 3 Mton/yr (Van Alphen, 1990; Fettweis et al.,2007). The resulting estimate for the transported mass of SPM along the Dutch coast is $22 \pm 10 \mathrm{Mton} / \mathrm{yr}$.

The study of SPM has become urgent in recent decades as the human pressure on coastal systems has increased, and negative effects of SPM - decreasing optical depth of the water column, carrying pollutants, harbor siltation - need to be mitigated. One of the gaps in the present day knowledge is the transport pattern of SPM near the shore. Large engineering works in coastal areas around the world might intervene with the SPM transport, but the effects are not always well understood. The use of bottom landers (Souza and Howarth, 2005; Cacchione et al., 2006; Manning and Bass, 2006) and satellite technology (Fettweis et al., 2007; Eleveld et al., 2008; Moreira et al., 2013) for monitoring in-situ concentrations of SPM has enormously increased our understanding of the 
transport of SPM. With bottom landers, details of the processes determining the vertical flux of SPM have been uncovered, by observing floc formation, settling velocities and turbulent fluxes (Friedrichs et al., 2000; Howarth et al., 2002; Manning and Bass, 2006). Satellites have proven to be useful for monitoring large areas and the large-scale dynamics. However, in regions with (temporary) stratified waters satellites may not be sufficient to localize the bulk of the SPM beneath the pycnocline, as is the case in the Dutch coastal zone (Joordens et al., 2001; Pietrzak et al., 2011). Geyer et al. (2004) concluded that the bottom part of the water column may hold most of the information with respect to cross-shelf transport and recommend further research focusing on near-bed observations. Therefore, in this study we use shipboard measurements with a vertical CTD profiling system to localize the transport pathway of SPM near the bed in the Dutch coastal zone.

The Dutch coastal zone borders the east-side of the southern North Sea.The residual current along the Dutch coast is generally northward due to a combination of the tides, the predominantly southwesterly winds and baroclinic effects (Otto et al., 1990). The southern North Sea is a shallow area. A tidal wave moves in an anti-clockwise direction through the sea with strong tidal currents near the coast, similar to a Kelvin wave. Surface turbulence by wind and waves has a marked effect on the stability of the water column and local resuspension of SPM (Stanev et al., 2009). Besides the limited depth, the research area is characterized by the large buoyancy flux from the Rhine-Meuse estuary. The discharge contributes to the fresher continental coastal water from Belgian waters up to the German Bight (Otto et al., 1990; Lacroix et al., 2004). North of the estuary mouth, along the closed Dutch coast the Rhine Region of Freshwater Influence (ROFI) is formed over a length of about $100 \mathrm{~km}$. Here, the fresh water plume competes with the mixing processes of the tidal current, wind and waves. Studies on the temporal stratification in the bulge and the plume of the Rhine ROFI show variations on tidal scales, where both the diurnal and the fortnightly scales are important (Simpson et al., 1990; Simpson and Souza, 1995; De Boer et al., 2006). 
Most research on ROFI's, river plumes and coastal buoyant currents on continental shelves has been focused on the interaction of turbulence, stratification and mixing. SPM transport in similar systems as the Rhine ROFI has been studied in the Liverpool Bay ROFI (Jago et al., 2007; Krivtsov et al., 2008; Souza and Lane, 2013), the Huanghe (Wright and Friedrichs, 2006) and Cassino Beach, Patos Lagoon (Guerra et al., 2009; Vinzon et al., 2009). These system are defined by Walsh and Nittrouer (2009) as EAD's, Estuarine Accumulation Dominated systems. EAD's are systems characterized by low river discharges. However the discharge of the Rhine-Meuse system doesn't qualify as low. A better definition here is to use the river plume classification proposed by Yankovsky and Chapman (1997), where the river discharge relative to the depth of the receiving shelf is used to define the plume along the coast. In this classification the Rhine ROFlis a bottom attached plume. The river discharge is large relative to the depth of the receiving continental shelf. This in contrast to the more commonly investigated surface advected plumes with a relatively small discharge compared to the shelf depth, such as the Hudson river plume and the Eel River shelf (Jurisa and Chant, 2012; Harris et al., 2005). Bottom attached plumes can potentially carry sediment further than surface attached plumes, because bottom resuspension can maintain sediment in the water column at large distances from the river mouth (Geyer et al., 2004). A difference with the plumes considered in Geyer et al. (2004) is that the input of SPM from the river Rhine itself is low. This sets the present study area apart from the Huanghe and the Patos Lagoon.

The research area is located in the far-field plume of the Rhine ROFI, about $80 \mathrm{~km}$ north of the estuary mouth, between IJmuiden and Den Helder (Figure 1). Previous observational programs in the Dutch coastal zone with a focus on SPM concentrations and transport concerned large-scale surface measurements and detailed in-situ measurements at Noordwijk (which is located just $40 \mathrm{~km}$ north of the estuary mouth, see Figure 1). The large-scale surface data were derived from satellite observations (Eleveld et al., 2008; Pietrzak et al., 2011, Fettweis et al., 2012) and the long-term surface monitoring program by the Dutch government (the so-called MWTL observations) (Visser et al., 1991). The observational programs at Noordwijk included both observations from moorings and 
shipboard observations at transects (Huthnance, 1997; Joordens et al., 2001; McCandliss et al., 2002; Howarth et al., 2002). Though these programs have much contributed to our present-day knowledge of general SPM processes and processes specific for this area, they lack the resolution in space and/or depth of the inner shelf in the area closer than $5 \mathrm{~km}$ from the coastline. Van Alphen (1990) had already found a spot of high turbidity at $5 \mathrm{~km}$ from the coastline at Noordwijk, but this has never been investigated further. In particular, it has remained unclear whether this was a mere accidental phenomenon or a persistent one. In this paper we will present repeated measurements in this zone with a high resolution in the cross-shore direction as well as in the vertical. With this we want to answer the research question: "Is the SPM in the Dutch coast - under the influence of a bottom attached plume - confined in a turbidity maximum close to the coast?" Moreover, we want to identify cross-shore transports responsible for the localized turbidity maximum. Section 2 describes the sailing strategy to localize and monitor the SPM maximum within the water column, both along a transect and within a tidal cycle. The results in Section 3 describe the location of a turbidity maximum zone (TMZ) measured at several transects along the coastline. Besides localizing the $T M Z$, we also show the variation of the peak concentrations with the tide as well as its variation between two opposing meteorological conditions. This is followed by a discussion on possible mechanisms responsible for the TMZ in Section 4, and a concluding Section 5.

\section{Measurements}

Measurements to obtain vertical profiles of SPM concentrations, water density and current velocities were carried out with RV Navicula during several non-consecutive days in the years 2003, 2010 and 2011. The main purpose was to obtain insight in the spatial and temporal variability of SPM in the nearshore coastal zone over different cross sections. 


\subsection{Study area}

The study area is located on the inner shelf along the coast of The Netherlands between IJmuiden and Den Helder (Figure 1). This coastline is characterized by a sandy shoreline with regularly spaced groins and 2 to 3 submerged natural sand bars in the nearshore zone. The seabed is predominantly covered with sands of size $125-250 \mu \mathrm{m}$, with some patches near the shore in which the mud content in the upper $20 \mathrm{~cm}$ is up to 10\% (Van Alphen, 1990; Irion and Zöllmer, 1999). South of the study area are the IJmuiden harbor jetties, north of the study area is the first and major inlet to the Wadden Sea situated. The tide travels along the coast in northward direction with an average tidal range at IJmuiden of $1.7 \mathrm{~m}$. Surface tidal velocities are stronger during flood than ebb and range between 0.7 and $1.1 \mathrm{~m} / \mathrm{s}$ (van der Giessen et al., 1990). The wind climate contributes significantly to the circulation of this shallow sea (Otto et al., 1990, Fettweis et al., 2012). The main wind direction is southwest, but most storms have a northwest direction. The study area is located in the far-field plume of the Rhine ROFI (Simpson et al., 1993; de Boer et al., 2009). Average surface salinities near the coast are 28-30 PSU (Visser et al., 1991). The freshwater input from the harbor of IJmuiden situated $8 \mathrm{~km}$ south of the area is small $\left(95 \mathrm{~m}^{3} / \mathrm{s}\right)$ as compared with the Rhine Meuse discharge (2500 $\left.\mathrm{m}^{3} / \mathrm{s}\right)$.

\subsection{Methods}

\subsubsection{Sailing strategy}

As the highest horizontal variation in the SPM concentration was expected perpendicular to the coast, a higher resolution in cross-shore than in longshore direction was taken. A number of transects was chosen perpendicular to the coast between IJmuiden and Callantsoog (Figure 1). Further north of Callantsoog, the Marsdiep ebb-tidal delta influences currents and sediment transport significantly and that area is therefore not included here. Each transect runs from $0.25 \mathrm{~km}$ until $7 \mathrm{~km} \mathrm{(2010} \mathrm{and}$ 2011) and $10 \mathrm{~km}$ (2003) from the coastline, with increased station spacing in the offshore direction of 250 to $2000 \mathrm{~m}$. The inshore station is usually in a water depth smaller than 6 meters, on the slope 
towards or on top of the outer breaker bank. It is known that further offshore from $7 \mathrm{~km}$ the SPM concentrations remain low (Visser et al., 1991; Joordens et al., 2001). At each station one CTD/OBS profile was taken and water samples were collected, while a vessel-mounted acoustic Doppler current profiler (ADCP) was continuously measuring current velocities.

The observations are divided into 10 single transect measurements (STMs) and 3 tidal cycle transect measurements (TCMs) (Table 1). The STMs have a high spatial and low temporal (ones a day) resolution, except for the Egmond transect in summer 2011 (twice a day). The TCMs have a low spatial resolution $(0.5,2$ and $5 \mathrm{~km})$, but a high temporal resolution as the transect is measured every hour during the tidal cycle. The TCM is always measured along the Wijk aan Zee transect, while the STMs are measured primarily along the upper three transects (Figure 1).

\subsubsection{Instrumentation}

At the stations a vertical profile of temperature, salinity and optical backscatter was made by lowering a lightweight frame from the afterdeck with a Seabird SBE 911plus CTD and a Seapoint OBS until it reached the seabed. The CTD instruments were located $0.5 \mathrm{~m}$ from the bottom of the CTD frame, and the OBS at $1.1 \mathrm{~m}$ from the bottom of the CTD frame. Data of the downcast are used for analysis and averaged within $25 \mathrm{~cm}$ bins. For the TCMs the upcast data are used because the downcast lack the data of the upper 2 meters. In contrast to other surveys, in our surveys both the upcast and downcast data can be used, because the frame does not contain Niskin bottles and the CTD is a pumped system. On a separate winch at the side of the ship a 5-liter Niskin bottle is lowered to take 2 water samples; one sample at about 1 meter above the bed and one sample at about 1 meter below the surface. The current velocity measurements were done with a vessel-mounted downward looking ADCP attached to the side of the ship at a water depth of $1 \mathrm{~m}$. Up to TCM1 (Table 1), a Nortek $1 \mathrm{MHz}$ ADCP was used with a bin size and blanking distance of $1 \mathrm{~m}$, and a measurement interval of $1 \mathrm{~s}$. From STM4 onwards, an RDI 1.2 MHz ADCP was used. Data was stored at an interval 
of $2 \mathrm{~s}$ using 4 pings per ensemble; the bin height and blanking distance were $0.5 \mathrm{~m}$. Data were averaged over 20 consecutive profiles (i.e. over 40 s).

\subsubsection{OBS - SPM calibration}

The calibration procedure of the OBS on the CTD-frame needs an extra conversion step, as the Niskin bottles are not connected to the CTD-frame. This causes samples and OBS measurements to be neither simultaneous nor at the same location. Direct calibration of the OBS with the filter samples is therefore not accurate. Instead, we used an additional Seapoint OBS located in a black box in the laboratory on board. Each cruise a calibration of this OBS lab for SPM concentrations was established, whereas a calibration between the $\mathrm{OBS}_{\mathrm{ctd}}$ and the $\mathrm{OBS}_{\mathrm{lab}}$ was performed only during the autumn 2010 survey (Van der Hout et al., 2012). This OBS-OBS relation is applied for the measurements of 2010 and 2011. For the 2003 measurements the relationship $\mathrm{OBS}_{\mathrm{ctd}}=\mathrm{OBS}_{\mathrm{lab}}$ is applied. The relation between the two OBSs was found to be stable over a year (Merckelbach and Ridderinkhof, 2006; Nauw et al., 2014). The calibration of the OBS lab for SPM concentrations was done as follows. From each water sample taken with the Niskin bottle, a subsample was taken for the SPM concentration measurement by filtration and another subsample was taken for the $\mathrm{OBS}_{\text {lab }}$ measurement in the black box, resulting in a voltage reading. The SPM concentration was determined by filtrating a subsample between 0.4 and $1 \mathrm{I}$, depending on turbidity, over a pre-dried and pre-weighted GF/F filter. The filter was then rinsed with demineralized water to capture all the particles on and remove excess salt from the filter. Afterwards, the filters were dried again for 2 hours at $110^{\circ}$ and re-weighed. The SPM concentration was calculated with the weight difference over the exact filtered volume.

Each survey required a new calibration of the OBS lab for SPM concentrations, because during each period of the year the suspended matter can have a different composition, which backscatters the infrared light of the OBS in a different manner (Downing, 2006). For each of the 6 different surveys listed in Table 1, a linear regression relation was calculated between OBS $\mathrm{Sab}_{\mathrm{ab}}$ and the SPM concentration with the MATLAB function "robustfit" using default settings (Figure 2). This linear 
regression method applies a weight to each data point, which is iteratively determined to reduce the influence of possible outliers on the regression line. The number of samples used for each calibration varied between 30 and 144, which depended on the number of transects per survey and the number of stations per transect. The regression lines in Figure 2 show a large spread in the directional coefficient between surveys, with a factor of 2 between the two extremes in 2003 and in autumn 2011.

\subsection{Conditions}

An overview of the conditions during the surveys is given in Table 1 . The total of 11 days cover three seasons; spring, summer and autumn. Maximum wave height during the surveys was $1.5 \mathrm{~m}$, which is the operational limit of the research vessel. A bias to calm conditions is thus inevitable. STMs were done in periods with a significant wave height ranging between $0.3-1.5 \mathrm{~m}$. This range is reflected by the wind force conditions varying between 2 and $5 \mathrm{Bft}$. The wind direction varied considerably between the surveys. We measured more in northerly winds as compared to a more common southwesterly wind in the yearly average. Usually one transect per day was surveyed, which occured during various phases of the semi-diurnal tidal cycle and of the spring-neap tidal cycle as indicated in Table 1. The three TCMs were all measured close to spring tide and under conditions with comparable significant wave heights (0.7-1.1 m). Main difference was the wind direction and the wind force.

\section{Results}

\subsection{Location of turbidity maximum}

In 2003, at all three STMs peaks in the SPM concentration were observed near the bed at the stations $0.5,1$ and $1.5 \mathrm{~km}$ from the shore. During the more extensive campaigns in 2010 and 2011 again near-bed peaks in the SPM concentrations were observed at all 10 STMs, similarly close to the 
shore. Some examples of the cross-shore distribution of the SPM concentration are shown in Figure 3 (see also Table 1 for the survey list). A persistent turbidity maximum was found near the seabed between $0.5 \mathrm{~km}$ and $3 \mathrm{~km}$ from the shore, present at each measured transect. This turbidity maximum may extend even further inshore, as in some STMs the high near-bed SPM concentrations extended up to the station nearest to the shore. The turbidity maximum was sometimes limited to a few meters above the bed (Figure $3 b, 3 c$ and $3 d$ ), but at other times also visible all the way up the surface (Figure 3a and Figure 5a). Within the turbidity maximum zone the highest concentrations were measured at $1.25-1.5 \mathrm{~km}$ from the shore in almost $50 \%$ of the surveys. In $25 \%$ of the other surveys the second highest peak is found within this same small region. Peak concentrations varied between 30 and $233 \mathrm{mg} / \mathrm{l}$. The water depth at the location of the peak concentration was on average 13 meters, and the water depth of the turbidity maximum zone stretches from $15 \mathrm{~m}$ until $4.5 \mathrm{~m}$ water depth and possibly even shallower.

\subsection{SPM concentration variation within a tidal cycle}

In order to evaluate the effect of the phase of the tidal current on the sediment concentration in the water column three tidal cycle measurements (TCMs) on the southern transect (Wijk aan Zee) were performed. We focus here on the results of TCM1, the survey on March 30, 2010 (Table 1). Three stations were successively occupied along the cross-section at $5 \mathrm{~km}, 2 \mathrm{~km}$ and $0.5 \mathrm{~km}$ from the coastline. Note that the central station is located in the turbidity maximum zone and $0.5 \mathrm{~km}$ seaward from the peak concentration location. The survey was started 1 hour before slack before ebb, and was ended 1.5 hours after maximum flood currents, amounting to a series of 12 transects in 12 hours (Figure 4a). The large variation in the depth of the profiles in Figure 4, is explained by the tidal range $(2 \mathrm{~m})$ and by sailing up and down the transect over an irregular bathymetry; as the location of the sampling stations varied slightly, so did the water depth.

Figure 4a shows the water level at IJmuiden, which has a tidal phase difference of 15 min with Wijk aan Zee, and the depth averaged velocity derived from the ADCP measurements at the station $2 \mathrm{~km}$ 
offshore. High water lagged the maximum flood velocity by one hour and low water occurs 3 hours after maximum ebb velocities. The tidal curve is strongly modified by higher harmonics such as the M4 tidal component, which strongly change the duration of the high and low water periods (Otto et al., 1990). The rising tide (low to high water) lasts for 4 hours, and the falling tide for 8.5 hours. The current velocity has a less asymmetric character with the ebb period lasting 6 hours and the flood period 6.5 hours. Maximum depth-averaged flood and ebb velocities were $0.8 \mathrm{~m} / \mathrm{s}$ and $0.5 \mathrm{~m} / \mathrm{s}$, respectively.

The low density anomaly of a 1.5 meter thick water layer in Figure $4 \mathrm{~b}$ is related to the presence of a freshwater lens at the surface and is observed during the first 11 hours of the survey. At the two other stations this freshwater lens was also present during the same period and had a similar thickness. The lens is thought to originate from the freshwater discharge sluices at IJmuiden. Below this lens a weak vertical stratification was present from 5:10 until 14:10. The intensity of the stratification varied over time, being minimal during peak (flood) velocities and maximal near the slacks. The relatively low densities in the measurement area are a result of the fresh water from the outflow of the river Rhine and from the fresh water discharge at IJmuiden. With the alternating tidal current, water with varying densities was advected through the measurement area. In other words, the ROFI plume is moving back and forth through the measurement area, while being enhanced locally by the discharge at the sluices near IJmuiden. Temperature differences had no significant effect on the observed density variations.

Surface concentrations at the central station ( $2 \mathrm{~km}$ from the shoreline) varied between 20 and 60 $\mathrm{mg} / \mathrm{l}$ (a factor 3), near-bed concentrations varied between 30 and $120 \mathrm{mg} / \mathrm{l}$. On average the concentration difference between the surface and near-bed was a factor of two, but varied between 1.5 and 10 within the tidal cycle. Peaks in near-bed concentrations and surface concentrations both occurred near the peak velocities. A marked phase lag between the surface and the near-bed concentrations is observed at the start of the ebb tidal phase, between 6:10 and 10:10 (Figure 4d). A 
phase lag between the surface SPM concentration and the tidal current occurs by the fact that vertical mixing of the SPM takes time. At the beginning of the ebb this phase lag was enlarged by the stratification. At 8:10 and 9:10 UTC the stratification limited the resuspension, while at other times the stratification did not halt resuspension. After reversal of the current at 7:10 UTC the near-bed concentrations increased, indicating local resuspension. As ebb currents increased, sediment was eventually mixed throughout the entire water column at 10:10. During this period the difference between the surface and the near-bed concentrations increased to a factor of 10 at 8:10, after which it decreased to 1.5. The depth-averaged concentration remained constant (solid red line in Figure 4d). On the flood tidal phase, after 13:10, the near-bed and the surface concentrations started to increase again and also deviate from each other even though there was no stratification. This is indicative of the phase lag of the surface concentrations without stratification. Besides lower surface concentrations, we also observed a smaller fluctuation in the surface concentrations than in the near-bed concentrations. This phenomenon is also related to the lag in the upward diffusion under alternating tidal currents (Yu et al., 2011).

Both the maximum and the depth averaged SPM concentrations at the offshore station $(5 \mathrm{~km}$ offshore)were lower than at the previously discussed central station (Figure 4d). Concentrations at this station also showed a positive relation with the tidal current, similar to the central station. The SPM concentrations at the inshore station ( $0.5 \mathrm{~km}$ offshore) showed no relation with the tidal current (dashed red line in Figure 4d). Depth averaged concentrations were similar to those of the central station, but maximum concentrations were lower; the sediment was more evenly distributed over the vertical.

The other two TCMs (TCM2 and TCM3; Table 1) showed the same patterns as TCM1, but with a few differences. A fresh water lens was not observed during the other two TCMs, although TCM2 contained a strong stratification in the upper 2 meters of the water column during the ebb phase of the tide. However, the minimum observed density anomaly was $20.5 \mathrm{~kg} / \mathrm{m}^{3}$, instead of nearly zero. In TCM2 and TCM3 also a weak stratification during the ebb phase was present, of which the timing of 
the onset and breakdown was slightly different. Similar correlations were found between the tidal current and the near-bed and surface SPM concentrations as in TCM1. Only in TCM2 the surface concentrations during ebb did not increase due to the strong stratification in the small surface layer. The surface concentrations in TCM2 and TCM3 were lower than in TCM1, which increased the factor between the near-bed and the surface concentration to 4 , instead of 3 . The depth-averaged concentration at the inshore station showed different patterns for all three TCMs. There was a positive relation with the tide for TCM2; while no relation for TCM3 and TCM1 was observed.

\subsection{Influence of wind, waves and spring-neap cycle}

In autumn 2010 the Egmond transect was surveyed in two consecutive weeks with opposing weather conditions and spring-neap tidal phase, STM5 and STM6 (Table 1). These two surveys represent the most extreme wind conditions in this observational program, both the most calm (STM6) and the most energetic condition (STM5). On November 1st it was neap tide and wind speed and wave heights were extremely low; the average wind speed was $1 \mathrm{Bft}$ from the northeast and the average wave height during the survey was $0.3 \mathrm{~m}$. The preceding day the wind was easterly and $3 \mathrm{Bft}$ and the average wave height was $0.6 \mathrm{~m}$, and the day before that the wave height was $1.3 \mathrm{~m}$. On October 26th it was one day after spring tide and the average wave height was $1.5 \mathrm{~m}$ with wind force $5 \mathrm{Bft}$ from the southwest, being still moderate wave conditions for the Dutch coastal zone. Hereafter we will refer to it as energetic conditions, to mark the contrast with the other surveys. The preceding two days wave heights were 1.8 and $2.5 \mathrm{~m}$, and the wind speed was between 4 and $6 \mathrm{Bft}$ from the north and northwest. The concentration distributions on the two transects in Figures 5a and $5 \mathrm{~d}$ show that during both conditions a turbidity maximum was present at the same location i.e. at 1 - $2 \mathrm{~km}$ from the shore. The distribution of the concentration during the energetic conditions was different from the overall cross-sectional picture displayed in Figure 3 and Figure $5 d$, which were observed during calm conditions. During energetic conditions, near the bed a layer of elevated concentrations of about $1 \mathrm{~m}$ thick was present at all measured stations in contrast to a single station at STMs during 
calm conditions. Moreover, above that high suspension layer, up to the surface, the sediment was almost homogeneously distributed in the vertical, and increasing in shoreward direction up to 1.25 $\mathrm{km}$ - the location of the peak concentration. During the energetic conditions the maximum concentration was higher - $55 \mathrm{mg} / \mathrm{l}$ versus $30 \mathrm{mg} / \mathrm{l}$ - and overall more material - approximately 4 times - was in suspension than during the calm conditions. The maximum concentrations were relatively low, because the measurements took place during slack after high water. In the previous section on the variation of the SPM concentration within a tidal cycle it was shown that during this phase of the tidal cycle the concentrations are lowest.

\section{Discussion}

In this study we have shown observations of a persistent turbidity maximum zone (TMZ) on various transects located between 0.5 and $3 \mathrm{~km}$ from the coast. It is present during different phases of the tide and under different meteorological conditions, which underlines its qualitative persistence. In this section, we explore its origin and some relevant physical factors.

\subsection{Tidal cycle dynamics}

Within a tidal cycle, two peaks in the near-bed concentration - one around maximum ebb and another around maximum flood currents - were found at the stations $2 \mathrm{~km}$ and $5 \mathrm{~km}$ offshore, respectively the station in the TMZ and the station offshore of the TMZ. The depth-averaged and peak concentrations at the stations inshore of the TMZ did not show a consistent relation with the tide. The timing of the maximum concentration with respect to the maximum of the tidal current is sometimes a little out of phase (Figure 4d), but it is important to realize that the sampling rate was only about once every hour. Thus the exact moments of the peaks may have been missed. This holds for both the concentration and the current, so, within that margin of uncertainty, the peaks can be regarded as 'simultaneous'. This strongly suggests that local resuspension, rather than advection, 
causes the high variations in the near-bed concentrations. The observed phase lag between the surface concentrations and the tidal current and the amplitude attenuation of the surface concentrations adds to the suggestion of local resuspension and settling by the tidal current being the most important process (Bass and et al., 2002; Yu et al., 2011).

\subsection{Periodic stratification}

Stratification can inhibit the resuspension of bottom sediments into the upper water column (Geyer, 1993), as has been observed to occur at Noordwijk in the near-field plume of the Rhine ROFI (Joordens et al., 2001). At each of our TCMs in the far-field of the plume, ebb phases of the tide were stratified, whereas flood phases were either mixed or in any case weaker stratified. SPM resuspension to the surface seemed to be inhibited due to the pycnocline only during a few observations during the stratified period. Other, more gradual density differences did not halt mixing of SPM into upper levels. Overall, lower surface concentrations were measured during the ebb phase than during the flood phase, which may be attributed to a lower turbulence by both the presence of the stratification and of the low ebb tidal current velocity. Interestingly, these observations show the onset of periodic stratification during spring tides as also observed by Nauw and Van der Vegt (2012). So far, modeling studies have indicated suppression of stratification during spring tides (De Boer et al., 2006; Pietrzak et al., 2011).

\subsection{Accumulating processes on the inner shelf}

The tidal resuspension and settling behavior suggests that a local source of SPM has to be present in the TMZ. There is no geological source of fine sediment in the seabed, thus the SPM has to accumulate there after advection into the area. About 22 \pm 10 Mton/yr SPM is transported northward with the residual northward current from the Strait of Dover. Along this transport path cross-shore physical processes and cross-shore (and onshore) transport of SPM have been measured and modelled at the Belgian coast (Fettweis and Van den Eynde, 2003; Lacroix et al., 2004), at the estuary mouth of the Rhine-Meuse related to the dynamics of the fresh water bulge (De Kok, 1992; Horner- 
Devine et al., 2014) and in the near-field plume at Noordwijk (Van der Giessen et al., 1990; Visser et al., 1991; Visser et al., 1994; De Boer et al., 2008). The nearshore presence of a turbidity maximum appears to be also a result of cross-shore processes related to the Rhine ROFI downstream of the research area.

For our research area three zones can be distinguished where different processes may influence the TMZ; 1) offshore of the TMZ: transport of offshore SPM towards the turbidity zone and 2) inshore of the TMZ: transport of surf-zone SPM in offshore direction and 3) in the TMZ: processes sustaining the SPM in the TMZ. Not all of these processes have been captured by the measurements described in this paper, but we will highlight the plausible mechanisms for the accumulation zone of SPM using literature. Onshore (offshore) transport in the near-bed layer can be caused by wind-induced upwelling (or downwelling) (Lentz and Fewings, 2012), asymmetry in cross-shore straining (Stacey et al., 2008) and Stokes drift from surface waves (Lentz and Fewings, 2012; Santamaria et al., 2013). Transport of SPM from the surf-zone in an offshore direction is considered to maintain the turbidity maximum zone at a distance from the shore. The location of the TMZ found in our surveys is also just at a location where a sharp change in the bed slope occurs. The downslope transport of a fluid mud layer from the surf-zone over the outer breaker bar is thought to be an offshore transport process occurring under storm conditions, and has been modelled for the Eel River and Cassino Beach systems (Harris et al., 2005; Vinzon et al., 2009). For the third zone two processes can be identified to play a role in sustaining the SPM in the TMZ; 1 ) observed high concentrations of the benthic species Ensis Directus can stabilize SPM in fecal pellets on the seabed (Armories and Reise, 1999; Grabowski et al., 2011; Witbaard et al., 2015), and 2) turbulence reduction by near-bed stratification due to high SPM concentrations will lead to SPM accumulation (Friedrichs et al., 2000).

\subsection{Cross-shore transport on a tidal cycle}

For the three TCMs we can identify the cross-shore transport at the three stations in and bordering the TMZ. We calculated the vertically integrated cross-shore transport at each station and the tidally 
integrated mass transport over the tidal cycle at each station. These values are shown in Figure 6. Offshore transport occurs mostly during the ebb phase of the tide. This results partly from the ellipticity of the tidal current (with a ellipticity coefficient of up to 0.1 ), and partly from the orientation of the $\mathrm{M} 2$ tidal current. The $\mathrm{M} 2$ major axis is directed towards the coast with 8 degrees, which is most likely a result of the diversion of the tidal current around the jetties at the harbor entrance of IJmuiden $8 \mathrm{~km}$ south of the transect. This curvature south of the Wijk aan Zee transect is visible in the bathymetry in Figure 1. Integrated over the tidal cycle the cross-shore transport is onshore at all stations except the $0.5 \mathrm{~km}$ station in Summer 2011 (TCM2). The cross-shore transports do not show a clear difference between the upwelling TCM1 and the downwelling TCMs; TCM2 and TCM3, one of the processes from the list pointed out in the previous paragraph. Asymmetry in the stratification at the slack tides has been observed and varies between the TCMs, but whether this process is significant in the residual cross-shore transport cannot be inferred from our measurements. The large differences in the tidally integrated mass transports between the stations show accumulation of SPM between the stations surrounding the TMZ at all three TCMs. A back of the envelope calculation of the average accumulation between two stations of on average $350 \mathrm{~kg} / \mathrm{m} / \mathrm{tide}$ integrated over $30 \mathrm{~km}$ coastline (the distance between Wijk aan Zee and Callantsoog) and over 706 tidal cycles per year amounts to $7 \mathrm{Mton} / \mathrm{year}$. This large accumulation in cross-shore direction is a significant percentage with respect to the estimated yearly residual longshore transport of about 22 Mton/year. Thus, processes under calm conditions ( $\mathrm{Hs}<1.5 \mathrm{~m}$, but spring tides) already contribute to the accumulation of SPM in the TMZ.

\section{Conclusion}

Current velocity, density and SPM concentration observations have been obtained during three surveys covering each an entire tidal cycle, each along a cross-shore transect at the Dutch coast near IJmuiden. Thus, we have presented a quasi-synoptic view covering the vertical, the cross-shore 
distance between the surf zone and up to $5 \mathrm{~km}$ off-coast, and the variation within a tidal cycle. Supplemented with other transects along the coast, collected with low time and high spatial resolution, we have been able to identify a persistent turbidity maximum zone (TMZ) at $0.5-3 \mathrm{~km}$ from the coast, with the peak concentration located at $1.25-1.5 \mathrm{~km}$ from the coast (Figure 3). Tidal currents, wind speed and wave height have a large effect on the resuspension of SPM due to the shallowness of the area, as we showed by contrasting 'calm' and 'energetic' conditions (Figure 5). The TMZ was found along a $30 \mathrm{~km}$ coastal stretch along the Dutch coast in the far-field plume of the Rhine region of freshwater influence (ROFI). The influence of the freshwater discharged $80 \mathrm{~km}$ south of the research area at the Rhine-Meuse mouth was still present in the form of a bottom attached plume. Alongshore and cross-shore density differences were measured, which showed periodic stratification during the ebb tidal phase. The much smaller freshwater discharge from IJmuiden at 8 $\mathrm{km}$ south of the research area was observed a single time as a freshwater lens floating on top of the stratified Rhine ROFI waters.

Concentrations of more than $100 \mathrm{mg} / \mathrm{l}$ were observed frequently in the study area, even though it is far from the main source area, Dover Strait.. This demonstrates the effect that bottom-attached plumes have on the transport of SPM far downstream of their origin as indicated by Geyer et al. (2004). We notice that Van Alphen (1990) already had found a similar turbidity maximum at $5 \mathrm{~km}$ from the coast at a more southerly location (Noordwijk), closer to the mouth of the estuary. This - in combination with several previously observed cross-shore and onshore transport processes between the SPM source and our study area - suggests that the TMZ probably extends all the way from the mouth of the Rhine-Meuse estuary up to Callantsoog, in the zone between the surf zone and $5 \mathrm{~km}$ from the coast.

Our combined observations of current velocities and SPM concentrations indicate a cross-shore net transport of SPM towards the TMZ over a tidal cycle, pointing to an accumulation under the conditions of our measurements, i.e. calm weather conditions. It is beyond the dataset presented 
here to determine what happens during storm conditions; conceivably the opposite could occur with offshore/diffusive processes. Several processes that may be (partly) responsible for the accumulation are listed in Section 4, but the number of observations was insufficient to determine the relative importance of the various processes. Moreover, the wind and wave conditions during our measurements were not representative for yearly conditions.

The measurements presented here imply that observations relying on surface measurements alone must be treated with caution in the sense that they offer no immediate clue to the concentrations in the water column as a whole. The observed strong vertical gradient in the concentration of SPM varied over the tidal cycle, which especially reduced the variation in the surface concentration signal. Three factors were observed that cause this variation in the vertical gradient; 1) a phase and amplitude lag with respect to the tidal current, 2) asymmetrical tidal currents, both in period of the different phases as well as in amplitude and 3) temporary stratification during the ebb phase of tide which temporarily inhibits resuspension of SPM to the surface.

\section{Acknowledgements}

We thank the captains and crew of R.V. Navicula and the technicians -Sven Ober and Eric Wagemaakers. Many thanks to colleagues at Royal NIOZ and students from the University of Utrecht for their assistance during the cruises. We would like to thank the two anonymous reviewers who helped to improve the manuscript significantly. This work was funded by the Ecoshape/Building with Nature innovation program, under project number NTW3.1. 


\section{References}

Armories W. and K. Reise 1999. On the population development of the razor clam Ensis americanus near the island of Sylt (North Sea). Helgolandes Meeresforschung 52, 291-300.

Bass, S.J., Aldridge, J.N., McCave, I.N., Vincent, C.E., 2002. Phase relationships between fine sediment suspensions and tidal currents in coastal seas. J. Geophys. Res. 107, 3146. doi:10.1029/2001JC001269

Cacchione, D. A., Sternberg, R.W., Ogston, A. S., 2006. Bottom instrumented tripods: History, applications, and impacts. Cont. Shelf Res. 26, 2319-2334. doi:10.1016/j.csr.2006.07.027

Downing, J., 2006. Twenty-five years with OBS sensors: The good, the bad, and the ugly. Cont. Shelf Res. 26, 2299-2318. doi:10.1016/j.csr.2006.07.018

Eleveld, M.A., Pasterkamp, R., van Der Woerd, H.J., Pietrzak, J.D., 2008. Remotely sensed seasonality in the spatial distribution of sea-surface suspended particulate matter in the southern North Sea. Estuar. Coast. Shelf Sci. 80, 103-113. doi:10.1016/j.ecss.2008.07.015

Fettweis, M., Van den Eynde, D., 2003. The mud deposits and the high turbidity in the Belgian-Dutch coastal zone, Southern bight of the North Sea. Cont. Shelf Res. 23, 669-691.

Fettweis, M., Nechad, B., Eynde, D. Van Den, 2007. An estimate of the suspended particulate matter (SPM) transport in the southern North Sea using SeaWiFS images, in situ measurements and numerical model results. Cont. Shelf Res. 27, 1568-1583. doi:10.1016/j.csr.2007.01.017

Fettweis, M., Monbaliu, J., Baeye, M., Nechad, B., Van den Eynde, D., 2012. Weather and climate induced spatial variability of surface suspended particulate matter concentration in the North Sea and the English Channel. Methods Oceanogr. 3-4, 25-39. doi:10.1016/j.mio.2012.11.001

Friedrichs, C.T., Wright, L.D., Hepworth, D.A., Kim, S.C., 2000. Bottom-boundary-layer processes associated with fine sediment accumulation in coastal seas and bays. Cont. Shelf Res. 20, 807-841.

Geyer, W.R., 1993. The Importance of Suppression of Turbulence by Stratification on the Estuarine Turbidity Maximum. Estuaries 16, 113. doi:10.2307/1352769

Geyer, W.R., Hill, P.S., Kineke, G.C., 2004. The transport, transformation and dispersal of sediment by buoyant coastal flows. Cont. Shelf Res. 24, 927-949. doi:10.1016/j.csr.2004.02.006

Grabowski, R.C., Droppo, I.G., Wharton, G., 2011. Erodibility of cohesive sediment: The importance of sediment properties. Earth-Science Rev. 105, 101-120. doi:10.1016/j.earscirev.2011.01.008

Guerra, J. V., Azevedo, M.M., Esteves, L.S., Vinzon, S.B., Violante-Carvalho, N., Schettini, C.A.F., Oliveira, R.F., Zaleski, A.R., 2009. Spatial and temporal variability of seawater properties, current velocity and SPM concentration off Cassino Beach-Rio Grande-Southern Brazil. Cont. Shelf Res. 29, 530-544. doi:10.1016/j.csr.2008.09.010 
Harris, C.K., Traykovski, P.A., Geyer, W.R., 2005. Flood dispersal and deposition by near-bed gravitational sediment flows and oceanographic transport: A numerical modeling study of the Eel River shelf, northern California. J. Geophys. Res. 110, C09025. doi:10.1029/2004JC002727

Horner-Devine, A.R., Pietrzak J., Stive M., Souza A., Meirelles S., Henriquez M., McKeon M., de Boer G., 2014. Cross-shore sediment transport due to near-shore frontal processes in the Rhine region of freshwater influence. American Geophysical Union, Ocean Sciences Meeting, Honolulu, HI, February 2014.

Howarth, M.J., Simpson, J.H., Sündermann, J., van Haren, H., 2002. Processes of Vertical Exchange in Shelf Seas ( PROVESS ). J. Sea Res. 47, 199-208.

Huthnance, J.M., 1997. The PROFILE project: an overview. J. Mar. Syst. 12, 249-261. doi:10.1016/S0924-7963(96)00101-7

Irion, G., Zöllmer, V., 1999. Clay mineral associations in fine-grained surface sediments of the North Sea. J. Sea Res. 41, 119-128.

Jago, C., Kennaway, G., Novarino, G., Jones, S., 2007. Size and settling velocity of suspended flocs during a Phaeocystis bloom in the tidally stirred Irish Sea, NW European shelf. Mar. Ecol. Prog. Ser. 345, 51-62. doi:10.3354/meps07006

Joordens, J.C.A., Souza, A.J., Visser, A., 2001. The influence of tidal straining and wind on suspended matter and phytoplankton distribution in the Rhine outflow region. Cont. Shelf Res. 21, 301325. doi:10.1016/S0278-4343(00)00095-9

Jurisa, J.T., Chant, R., 2012. The coupled Hudson River estuarine-plume response to variable wind and river forcings. Ocean Dyn. 62, 771-784. doi:10.1007/s10236-012-0527-7

Krivtsov, V., Howarth, M.J., Jones, S.E., Souza, a. J., Jago, C.F., 2008. Monitoring and modelling of the Irish Sea and Liverpool Bay: An overview and an SPM case study. Ecol. Modell. 212, 37-52. doi:10.1016/j.ecolmodel.2007.10.038

Lacroix, G., Ruddick, K., Ozer, J., Lancelot, C., 2004. Modelling the impact of the Scheldt and Rhine/Meuse plumes on the salinity distribution in Belgian waters (southern North Sea). J. Sea Res. 52, 149-163. doi:10.1016/j.seares.2004.01.003

Lentz, S.J., Fewings, M.R., 2012. The wind- and wave-driven inner-shelf circulation. Ann. Rev. Mar. Sci. 4, 317-43. doi:10.1146/annurev-marine-120709-142745

Manning, A.J., Bass, S.J., 2006. Variability in cohesive sediment settling fluxes: Observations under different estuarine tidal conditions. Mar. Geol. 235, 177-192. doi:10.1016/j.margeo.2006.10.013

McCandliss, R.R., Jones, S.E., Hearn, M., Latter, R., Jago, C.F., 2002. Dynamics of suspended particles in coastal waters (southern North Sea) during a spring bloom. J. Sea Res. 47, 285-302. doi:10.1016/S1385-1101(02)00123-5 
McManus, J.P., Prandle, D., 1997. Development of a model to reproduce observed suspended sediment distributions in the southern North Sea using Principal Component Analysis and Multiple Linear Regression. Cont. Shelf Res. 17, 761-778.

Merckelbach, L.M., Ridderinkhof, H., 2006. Estimating suspended sediment concentration using backscatterance from an acoustic Doppler profiling current meter at a site with strong tidal currents. Ocean Dyn. 153-168. doi:10.1007/s10236-005-0036-z

Moreira, D., Simionato, C.G., Gohin, F., Cayocca, F., Luz Clara Tejedor, M., 2013. Suspended matter mean distribution and seasonal cycle in the Río de La Plata estuary and the adjacent shelf from ocean color satellite (MODIS) and in-situ observations. Cont. Shelf Res. 68, 51-66. doi:10.1016/j.csr.2013.08.015

Nauw, J.J., van der Vegt, M., 2012. Hydrodynamics of the Rhine ROFI near IJmuiden. NCK-days 2012Crossing borders Coast. Res. Jubil. Conf. Proc. 1. doi:10.3990/2.191

Nauw, J.J., Merckelbach, L.M., Ridderinkhof, H., van Aken, H.M., 2014. Long-term ferry-based observations of the suspended sediment fluxes through the Marsdiep inlet using acoustic Doppler current profilers. J. Sea Res. 87, 17-29. doi:10.1016/j.seares.2013.11.013

Otto, L., Zimmerman, J.T.F., Furnes, G.K., Mork, M., Saetre, R., Becker, G., 1990. Review of the physical oceanography of the North Sea. Netherlands J. Sea Res. 26, 161-238.

Pietrzak, J.D., de Boer, G.J., Eleveld, M.A., 2011. Mechanisms controlling the intra-annual mesoscale variability of SST and SPM in the southern North Sea. Cont. Shelf Res. 31, 594-610. doi:10.1016/j.csr.2010.12.014

Santamaria, F., Boffetta, G., Martins Afonso, M., Mazzino, a., Onorato, M., Pugliese, D., 2013. Stokes drift for inertial particles transported by water waves. EPL (Europhysics Lett. 102, 14003. doi:10.1209/0295-5075/102/14003

Simpson, J.H., Brown, J., Matthews, J., Allen, G., 1990. Tidal Straining, Density Currents, and Stirring in the Control of Estuarine Stratification. Estuaries 13, 125. doi:10.2307/1351581

Simpson, J.H., Bos, W.G., Schirmer, F., Souza, A.J., Rippeth, T.P., Jones, S.E., Hydes, D., 1993. Periodic stratification in the Rhine ROFI in the North Sea. Oceanol. Acta 16, 23-32.

Simpson, J.H., Souza, A.J., 1995. Semidiurnal switching of stratification in the region of freshwater influence of the Rhine. J. Geophys. Res. 100, 7037-7044.

Souza, A.J., Howarth, M.J., 2005. Estimates of Reynolds stress in a highly energetic shelf sea. Ocean Dyn. 55, 490-498. doi:10.1007/s10236-005-0012-7

Souza, A.J., Lane, A., 2013. Effects of freshwater inflow on sediment transport. J. Oper. Oceanogr. 6, 27-31.

Stacey, M.T., Fram, J.P., Chow, F.K., 2008. Role of tidally periodic density stratification in the creation of estuarine subtidal circulation. J. Geophys. Res. 113, C08016. doi:10.1029/2007JC004581 
Stanev, E.V., Dobrynin, M., Pleskachevsky, A., Grayek, S., Günther, H., 2009. Bed shear stress in the southern North Sea as an important driver for suspended sediment dynamics. Ocean Dyn. 59, 183-194. doi:10.1007/s10236-008-0171-4

Van Alphen, J.S.L.J., 1990. A mud balance for Belgian-Dutch coastal waters between 1969 and 1986. Netherlands J. Sea Res. 25, 19-30.

Van der Giessen, A., de Ruijter, W.P.M., Borst, J.C., 1990. Three-dimensional current structure in the Dutch coastal zone. Netherlands J. Sea Res. 25, 45-55.

Van der Hout, C.M. van der, Gerkema, T., Nauw, J., Ridderinkhof, H., 2012. Observations of suspended matter along the Dutch coast, in: NCK-Days 2012 : Crossing Borders in Coastal Research., 13 March 2012 - 16 March 2012, Enschede, the Netherlands. pp. 213-217. doi:10.3990/2.200

Vinzon, S.B., Winterwerp, J.C., Nogueira, R., de Boer, G.J., 2009. Mud deposit formation on the open coast of the larger Patos Lagoon-Cassino Beach system. Cont. Shelf Res. 29, 572-588. doi:10.1016/j.csr.2008.09.021

Visser, M., de Ruijter, W.P.M., Postma, L., 1991. The distribution of suspended matter in the Dutch coastal zone. Netherlands J. Sea Res. 27, 127-143.

Visser, A.W., Souza, A.J., Hessner, K., Simpson, J.H., 1994. The effect of stratification on tidal current profiles in a region of freshwater influence. Oceanol. Acta 17, 369-381.

Walsh, J.P., Nittrouer, C.A., 2009. Understanding fine-grained river-sediment dispersal on continental margins. Mar. Geol. 263, 34-45. doi:10.1016/j.margeo.2009.03.016

Witbaard, R., Duineveld, G.C.A., Bergman, M.J.N., Witte, H.I., Groot, L., Rozemeijer, M.J.C., 2015. The growth and dynamics of Ensis directus in the near-shore Dutch coastal zone of the North Sea. J. Sea Res. 95, 95-105.

Wright, L.D., Friedrichs, C.T., 2006. Gravity-driven sediment transport on continental shelves: A status report. Cont. Shelf Res. 26, 2092-2107. doi:10.1016/j.csr.2006.07.008

Yankovsky, A.E., Chapman, D.C., 1997. A Simple Theory for the Fate of Buoyant Coastal Discharges. J. Phys. Oceanogr. 27, 1386-1401. doi:10.1175/1520-0485(1997)

Yu, Q., Flemming, B.W., Gao, S., 2011. Tide-induced vertical suspended sediment concentration profiles: phase lag and amplitude attenuation. Ocean Dyn. 61, 403-410. doi:10.1007/s10236010-0335-x 


\section{Figures and tables}
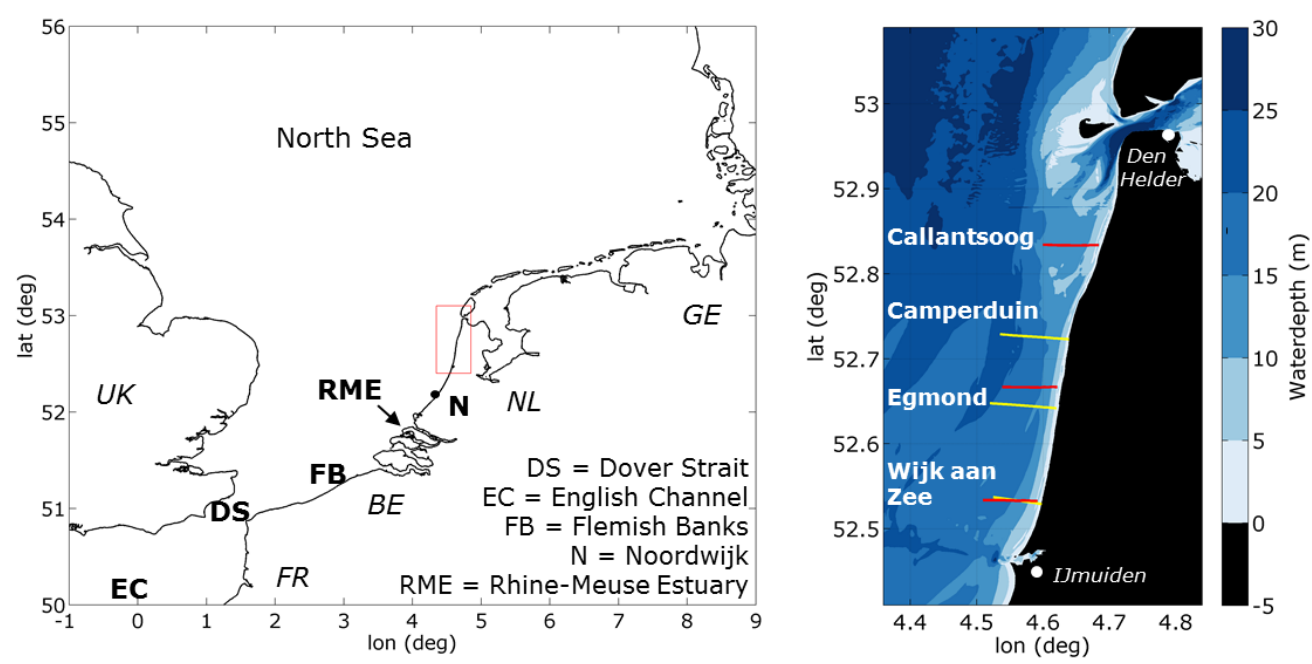

Figure 1. Maps of the study area. Left: The location of the study area along the Dutch Coast in the southern North Sea. The red rectangle marks the study area and is enlarged on the right. Right: Locations of the transects along the Dutch coast (water depths obtained from Rijkswaterstaat). Transect names are indicated in white. Four transect locations are specified for 6 different transect lines, named from north to south; Callantsoog, Camperduin, Egmond and Wijk aan Zee. The red transects were surveyed in 2003; the yellow transects in 2010 and 2011. 


\begin{tabular}{|c|c|c|c|c|c|c|c|c|c|c|c|c|}
\hline Survey & Survey week & Date & Location & $\begin{array}{l}\text { Daily mean } \\
\text { wind force } \\
\text { (Bft) and } \\
\text { direction }\end{array}$ & $\begin{array}{l}\text { Wave } \\
\text { height } \\
\text { Hs (m) }\end{array}$ & $\begin{array}{l}\text { Time of high } \\
\text { water (UTC) }\end{array}$ & $\begin{array}{l}\text { Neap tide (NT) - } \\
\text { spring tide (ST) } \\
\text { period }\end{array}$ & $\begin{array}{c}\mathrm{Cmax} \\
(\mathrm{mg} / \mathrm{I})\end{array}$ & $\begin{array}{c}\text { Distance } \\
\text { Cmax } \\
\text { from } \\
\text { coast }(\mathrm{km})\end{array}$ & $\begin{array}{l}\text { Time } \\
\text { cmax } \\
\text { (UTC) }\end{array}$ & $\begin{array}{l}\Delta \rho \_ \text {max } \\
\text { vertical }\end{array}$ & $\begin{array}{c}\Delta \rho \_m a x \\
\text { horizontal }\end{array}$ \\
\hline STM1 & Spring 2003 & $2003 / 04 / 22$ & Callantsoog & $2 \mathrm{NW}$ & 0.4 & 7:00 / 19:30 & 3 days before NT & 123 & 0.5 & $8: 57$ & 0.15 & 0.72 \\
\hline STM2 & & $2003 / 04 / 22$ & Egmond & $2 \mathrm{NW}$ & 0.4 & 7:00 / 19:30 & 3 days before NT & 183 & 0.5 & 13:09 & 0.11 & 0.62 \\
\hline STM3 & & $2003 / 04 / 23$ & Wijk aan Zee & $3 \mathrm{~N}$ & 0.4 & $8: 20 / 21: 00$ & 2 days before NT & 233 & 1.6 & $6: 22$ & 0.22 & 1.05 \\
\hline TCM1 & Spring 2010a & $2010 / 03 / 30$ & Wijk aan Zee & $4 \mathrm{~S}$ & 0.7 & $2: 50 / 15: 10$ & 2 days before ST & 117 & 2 & $16: 10$ & 22.31 & 7.82 \\
\hline STM4 & Spring 2010b & $2010 / 04 / 28$ & Camperduin & $4 \mathrm{~S}$ & 0.5 & $2: 40 / 15: 00$ & 2 days before ST & 74 & 1.5 & $11: 12$ & 0.38 & 1.25 \\
\hline STM5 & Autumn 2010 & $2010 / 10 / 26$ & Egmond & $5 \mathrm{SW}$ & 1.5 & $4: 30 / 16: 40$ & 1 day after ST & 55 & 1.5 & $8: 10$ & 0.18 & 0.81 \\
\hline STM6 & & 2010/11/01 & Egmond & $1 \mathrm{NE}$ & 0.3 & $10: 10 / 22: 50$ & NT & 30 & 1.25 & $13: 34$ & 1.49 & 1.37 \\
\hline STM7 & Summer 2011 & $2011 / 08 / 31$ & Egmond & $3 \mathrm{NW}$ & 1.1 & $4: 10 / 17: 20$ & ST & 66 & 3 & 8:06 & 0.09 & 0.87 \\
\hline STM8 & & 2011/08/31 & Egmond & $3 \mathrm{NW}$ & 1.1 & $4: 10 / 17: 20$ & ST & 226 & 1.5 & $9: 50$ & 0.18 & 0.73 \\
\hline TCM2 & & 2011/09/01 & Wijk aan Zee & $2 \mathrm{NE}$ & 1 & $5: 50 / 17: 20$ & 1 day after ST & 226 & 0.5 & $5: 30$ & 0.83 & 1.35 \\
\hline STM9 & & 2011/09/02 & Camperduin & $3 \mathrm{NE}$ & 0.7 & $5: 40 / 18: 10$ & 2 days after ST & 130 & 1.25 & $6: 12$ & 0.84 & 1.21 \\
\hline TCM3 & Autumn 2011 & $2011 / 10 / 13$ & Wijk aan Zee & $3 E$ & 1.1 & $3: 30 / 15: 50$ & 1 day before ST & 140 & 1 & $15: 02$ & 1.02 & 1.13 \\
\hline STM10 & & $2011 / 10 / 14$ & Camperduin & $3 E$ & 0.8 & $4: 10 / 16: 20$ & ST & 135 & 1 & $11: 22$ & 0.19 & 0.67 \\
\hline
\end{tabular}

Table 1. Details of location, time, conditions and main physical parameters for each survey. The surveys are subdivided into STMs (single transect measurements) and TCMs (tidal cycle measurements) and per survey week (column 2). Averaged wind, wave and tidal conditions during the survey periods are given in columns 5-8. Wind force and direction are recorded at the IJmuiden harbour (source: KNMI), significant wave heights and -directions at IJmuiden ammunition dumping ground, located $36 \mathrm{~km}$ offshore of IJmuiden (source: Rijkswaterstaat) and tidal elevation at Petten, which is $5 \mathrm{~km}$ north of Camperduin (source: Rijkswaterstaat). The maximum observed SPM concentration (Cmax), its distance from the coast and the time of its observation (indicative of the tidal phase) are shown in columns 9-11. Columns 12 and 13 give the maximum vertical and horizontal density difference of a survey.

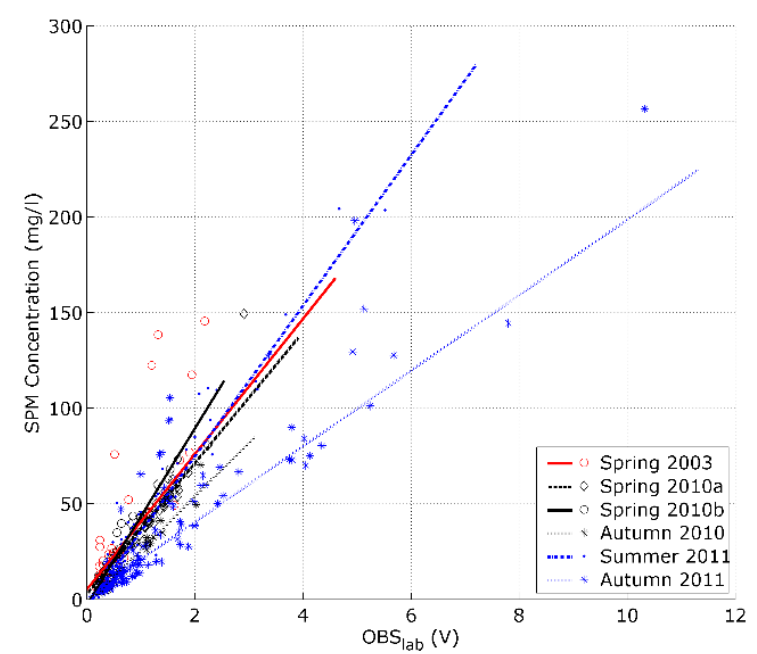




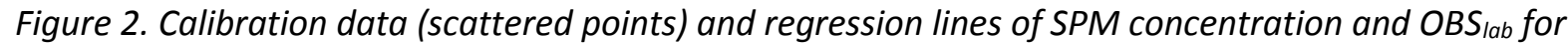
the 6 different survey weeks (Table 1).
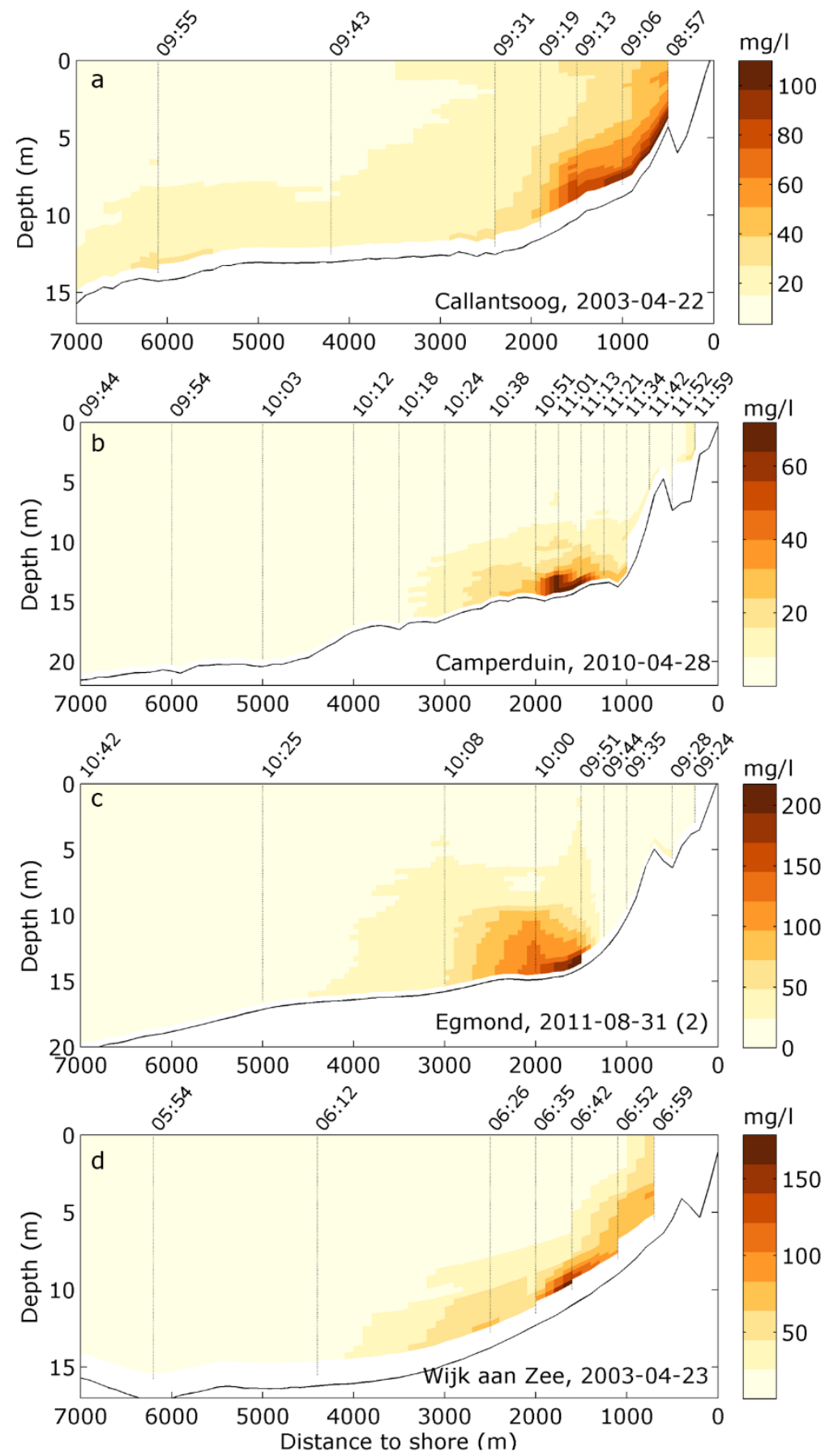

Figure 3. SPM concentrations $(\mathrm{mg} / \mathrm{ll})$ at four transects perpendicular to the coast. Locations and times of CTD/OBS-casts are indicated by a black vertical dashed line. The cross-sections correspond with the four labeled transects indicated in Figure 1 and Table 1: a) Callantsoog: STM1; b) Camperduin: STM4; c) Egmond: STM8; and d) Wijk aan Zee: STM3. 

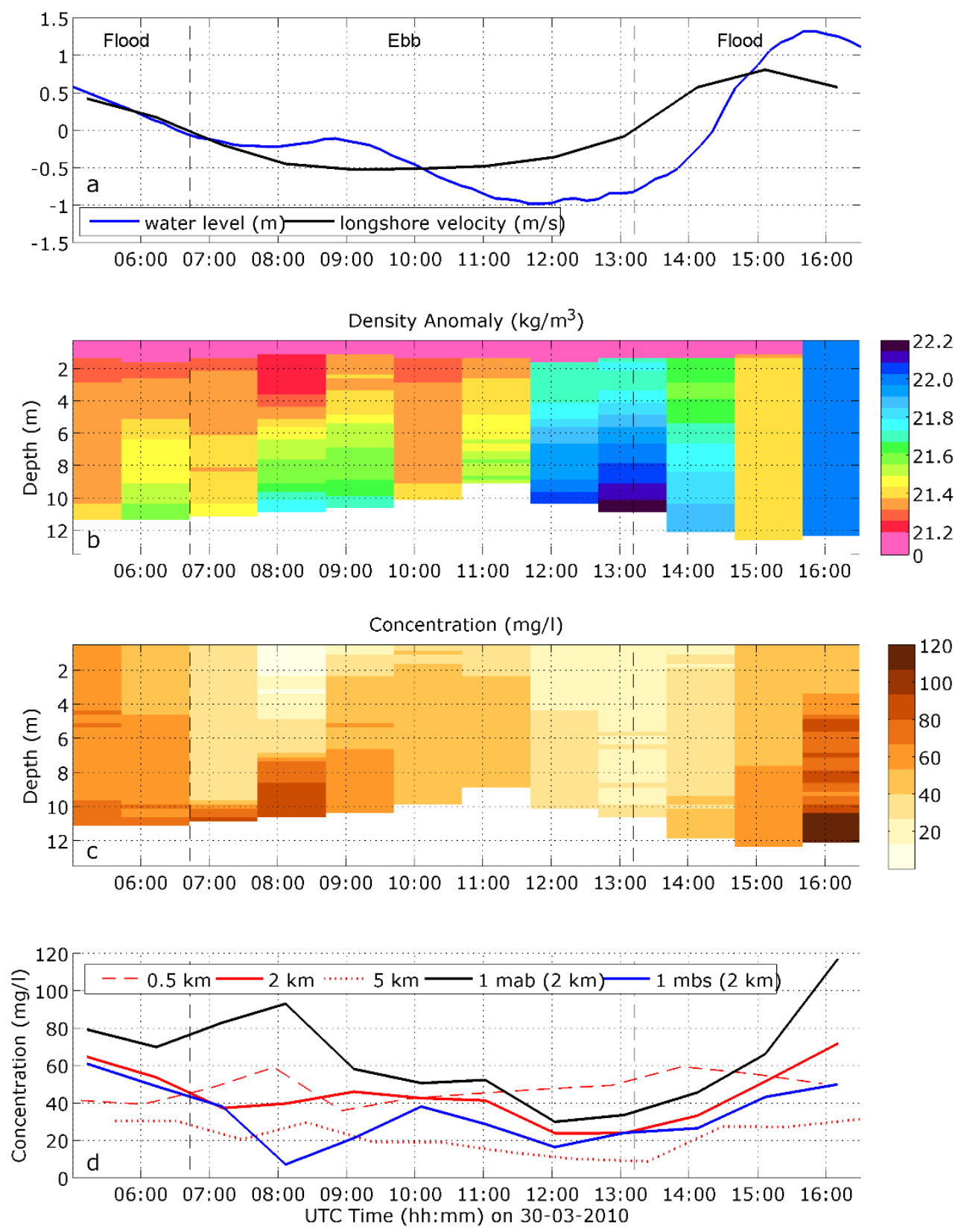

Figure 4. A tidal cycle of hydrodynamics and SPM concentrations at the transect Wijk aan Zee on March 30, 2010 during the Spring 2010 cruise (TCM1 in Table 1). Data are from the $2 \mathrm{~km}$ station unless stated otherwise. a) Water level at IJmuiden (m) (source: Rijkswaterstaat) and depth averaged longshore velocity ( $\mathrm{m} / \mathrm{s}$, positive velocities are northward). b) Vertical profiles of density anomaly from CTD-casts in time. c) Vertical profiles of SPM concentrations ( $\mathrm{mg} / \mathrm{ll}$ ) from CTD-casts in time. d) Depth-averaged SPM concentrations at the inshore station (0.5 km from the coast), the central station ( $2 \mathrm{~km}$ from the coast) and the offshore station ( $5 \mathrm{~km}$ from the coast) and concentrations 1 meter above the bed ( $1 \mathrm{mab})$ and 1 meter below the surface $(1 \mathrm{mbs})$ at the central station. Vertical dashed lines indicate slack tide. 

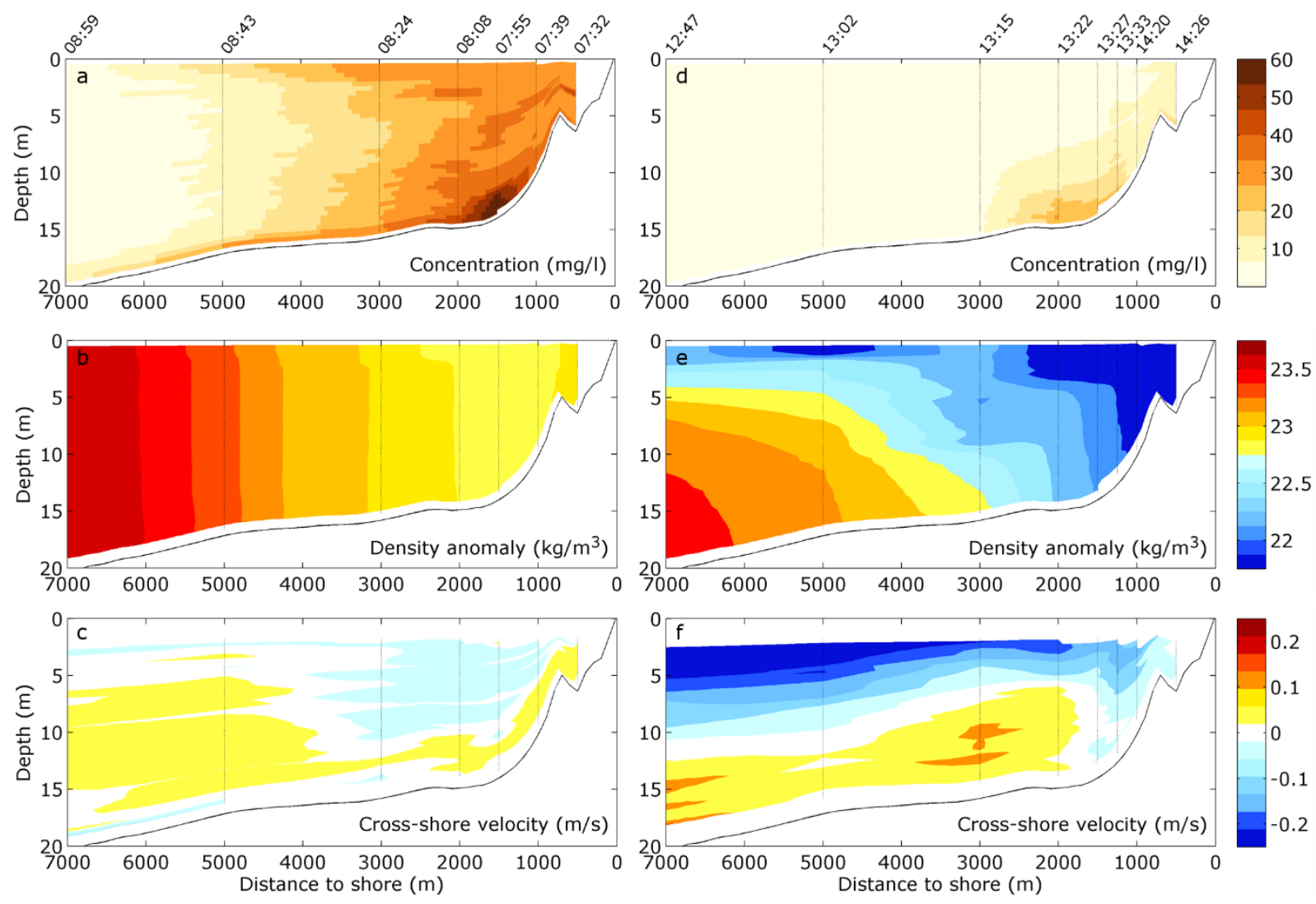

Figure 5. Contrasting weather conditions; energetic (left, STM5) versus calm (right, STM6). Crossshore sections of SPM concentration $(a+d)$, density anomaly $(b+e)$ and cross-shore current velocities $(c+f)$. Locations of CTD/OBS-casts are indicated as vertical dashed lines. Both surveys were carried out at slack tide after high water. Contour lines of concentration are spaced every $7.5 \mathrm{mg} / \mathrm{l}$, of density anomaly every $0.25 \mathrm{~kg} / \mathrm{m}^{3}$ and of velocity every $0.05 \mathrm{~m} / \mathrm{s}$, positive velocities are shoreward. 

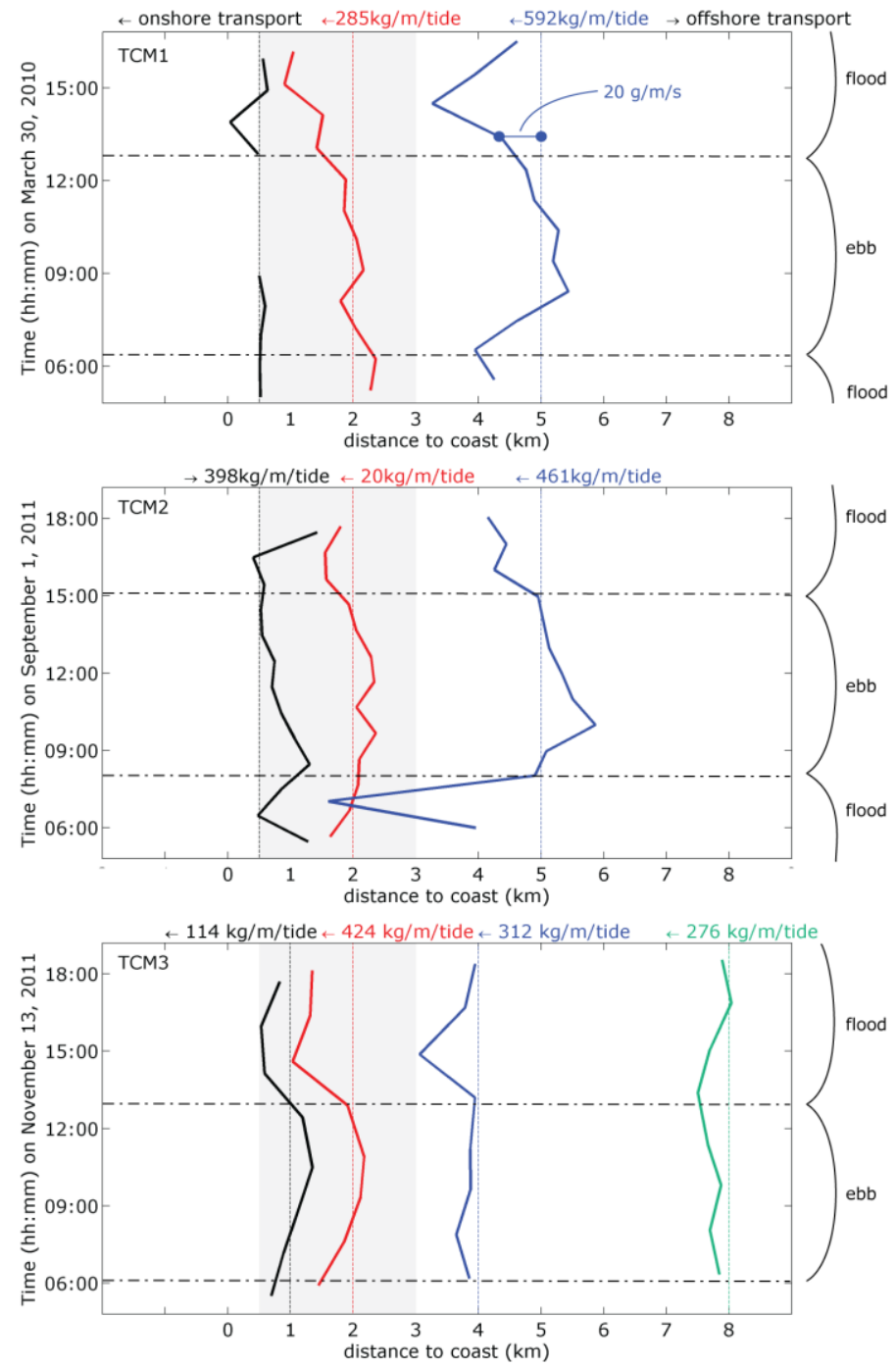

Figure 6.The cross-shore transport of SPM at different stations (indicated by different colors, with increasing distance from the coast: black, red, blue and green) and its variation over a tidal cycle (vertical axis). The dashed vertical lines indicate the locations of the stations, in terms of distance to the coast. The departure of the thick line from the dashed vertical line indicates the vertically integrated cross-shore transport; leftward displacements indicate onshore transport, rightward displacements indicate offshore transport. The TMZ is indicated by the grey area between 0.5 and 3 $\mathrm{km}$ from the coast. Above each graph, the integrated cross-shore transport over the measured tidal cycle is given with the resulting direction indicated by the arrow, and the color refers to the station. For the $0.5 \mathrm{~km}$ station (black line) in TCM1 there was no overlapping ADCP and CTD data available for the ebb tidal phase to calculate the cross-shore transport. 